\title{
GROSS MARGIN AS AN INDICATOR OF THE SIGNIFICANCE OF FARMER EDUCATION ON THE WCR RISK ASSESSMENT IN REPEATED SOWING ${ }^{1}$
}

\author{
Jasmina Filipovic ${ }^{2}$, Slađan Stanković3 ${ }^{3}$ Slobodan Ceranic ${ }^{4}$
}

\section{Summary}

Western corn rootworm (WCR) appeared in Serbia in the late 80's and quickly spread, causing increasing losses. Monitoring showed that crop rotation gives good results. On the other hand, domestic animals require a lot of corn and considering the limited landarea, that often demands repeated sowing of corn (continuous cropping), consequently leading to higher pest damages. Through Farmer Field Schools, farmers were educated on $W C R$ risk assessment of repeated corn sowing. The goal was to prolong corn production over years, presuming its higher profitability of production (gross margin). Calculations of production of wheat, corn and soybean on farms involved in education program in 2012, have shown that corn has the highest gross margin (92,047.50 RSD/ha), followed by soybean $(72,410.00 \mathrm{RSD} / \mathrm{ha})$ and wheat $(59,510.00 \mathrm{RSD} / \mathrm{ha})$. It could be concluded that farmer's best interest is to grow corn, when possible, in continuous cropping, with obligatory risk assessment.

Key words: corn, western corn rootworm, production, gross margin, investment, cost, education.

JEL: $Q 12, Q 16$

\section{Introduction}

The appearance of Western corn rootworm (WCR) in our country in the late 80's and damage it has caused, has led to important changes in the way of corn production. Corn rootworm is biologically adapted to corn in repeated sowing. In the first year, its larvae finish developing on

1 Paper is a part of a research within the project no. III 46008, financed by Ministry of Education, Science and Technological Development of Republic of Serbia.

2 Jasmina Filipović, M.Sc., Agricultural Extension Service Jagodina, Kapetana Koce Street no. 21, 35000 Jagodina, Serbia, Phone: +381 35221 931, E-mail: mina66@open.telekom.rs

3 Slađan Stanković, Ph.D., Institute for Science Application in Agriculture, Bulevar Despota Stefana Street no. 68b, 11000 Belgrade, Serbia, Phone: +381 6370038 62, Email: ssladjan@beotel.net

4 Slobodan Ceranić, Ph.D., full professor, Faculty of Agriculture, University in Belgrade, Nemanjina Street no. 6, 11080 Zemun, Serbia, Phone: +381 1126153 15, E-mail: ceranic@agrif.bg.ac.rs 
the corn root in June and in August adult females lay eggs in the field with corn. In the second year, the larvae are being sawed from the overwintering eggs. They feed on the corn roots in repeated sawing, so those larvae finish their development and the adult insects can start a new generation. WCR damage has brought up the question what is the most efficient way to suppress this pest. Considering the above mentioned, it is clear that it is enough to break the life and feeding cycle of the insects by changing a host plant, which is called crop rotation. The massive use of crop rotation in regions where farmers have specialized in growing corn as a monoculture has led to a decrease in area under corn in Serbia. Considering that farmers are not familiar with the ways to determine whether they need to take protective measures or not, it was done without knowing the real needs.

However, after 2000 in a large part of Serbia this damage has drastically decreased. The main reason for it was the negative effect of the climate conditions in 2000, the year with the lowest precipitation in the last 100 years and very high temperatures of air. Moreover, the massive use of crop rotation also affected the decrease in numbers of corn rootworm (Stanković, Sivčev, 2004).

Corn is an important crop in Serbia. It is well known that WCR has inhabited this region, but there have been no information about the damage this insect causes. There were no reliable data that would confirm pest status of corn rootworm in this part of Serbia. Over the past few years soybean has been grown more and more massively in this region. It is a common crop included in rotations with corn, but that is not an efficient way of suppressing Western corn rootworm (Gray et al., 1998).

The diversity of the plant and animal world is one of the most important factors and indicators of the WCR economic damage. It is the well-known fact that the rich plant diversity, WCR is the smaller problem for corn. This insect is number one pest in parts of the USA where soybean and corn are grown predominantly (for instance in Iowa, where on 13.2 million ha of arable land, 5 million ha is under corn and 3.5 million ha under soy), which indicates a poor biodiversity.

In Serbia, according to Agricultural Census 2012, corn is grown on 976,612 ha (grain corn plus 27,187 ha of corn for fodder), while wheat, sunflower, soy and alfalfa are grown on $602,844,186,361,181,684$ and 103,316 ha, respectively (SORS, 2014). Considering this, we can conclude that Serbia has high crop diversity and, consequently, we can expect problems with corn rootworm to appear in smaller extent, mainly on a corn in continuous cropping. It could be concluded, that the high crop diversity undoubtedly decreases the potential for corn rootworm in this area to develop into a pest like the one in the USA.

In addition to plant diversity, especially the diversity of crops, the richness of animal life, especially the domestic animals also have an impact. Domestic animals, particularly pigs and poultry use a lot of corn which, considering the limited amount of land often means repeatedly sowing of corn (growing it as a long-term monoculture). Therefore the sowing structure in areas with intensive livestock production has increased portion of corn and consequently higher WCR damages. Accordingly, a large concentration of farms with intensive livestock production stimulates the production of corn in monoculture, even with the massive WCR 
appearance and damage caused by it, especially having in mind farm structure in Serbia (Munćan, Živković, 2006).

For all these reasons, there was a need to monitor the number of WCR populations on farms in Serbia that are important producers of corn and soy. Considering the diversity of crops in these regions we pay special attention to corn and soy, which are potentially the most promising WCR hosts. We assume that WCR cannot fulfil its harmful potential due to a high biodiversity in this area and the regular use of crop rotation. Thus it is important to determine the population number and risk of damage on selected corn fields, as well as the significance of this one of the most destructive pests. Therefore there is a need for making and introducing a method for determination population density and having a reliable and economically viable method that would be a basis for implementing the ecological management of this harmful species. It is of great importance to test the models of knowledge transfer and training of both trainers and farmers.

The appearance of corn rootworm in our country has worried farmers very much. On the other hand, almost a geometric progression rate of damage caused by this pest has become a matter of interest of seed and pesticide companies. A very different method of control of this pest than the one in the US has showed as more efficient in our fields, because our agricultural conditions are different than the ones in the US Corn Belt.

Corn rootworm feeding \& damage: crops are damaged by the adult and larval stage, but economically important are caused by larvae that live in the soil and feed on roots. Adult insects are polyphagous species and damage they cause are of secondary importance. Besides corn, they also feed on other crops from the family Poaceae, and plants from the families Fabaceae and Cucurbitaceae (Purdue University, 1995). Adult insects feed first on leaves, then the pollen, corn silk and the top of the corn. The first adult insects that appear in the vegetative stage of corn feed appear on leaves. Once the blooming starts, adult insects start feeding on the pollen and the corn silk. This is the time when a large number of them can be found on the tassel and silk. The feeding of adult insects does not affect the income from corn. That happens only when there are a lot of adult insects prior to pollination, which completely eat the corn silk so that the cob is bare in the pollinating period. That kind of feeding results in the appearance of rough or partially rough cobs.

This research was aimed to show that the ecological approach (systematic environmental protection) to solving the problem of corn rootworm protection in the conditions of a higher biodiversity is more important to farmers than other methods, because it is more efficient, cheaper, viable and ecologically acceptable. We assumed that crop rotation was more efficient, which has been tested on many corn fields with damage caused by WCR. To test this hypothesis in production conditions, some new methods were applied that confirmed the assumptions and contributed to the results justification. This way of corn rootworm control is mostly for small scale farmers, with a diverse production (mixed animal and field crop production), who have an interest of growing corn in a repeated seeding, whenever possible. On the economic side, it is important for farmers to be introduced to the economic effect of a certain production. Gross margin is a quick and efficient indicator for comparing different 
production lines (enterprises) and choosing the most economic one (Tomić et al., 2013). Janković et al. (2007) showed that corn production gives the highest gross margin value per hectare of all field crops.

\section{Materials and Methods}

\section{Gross margin calculation}

Gross margin was used as an indicator of economic effects of maize grain production (Anđelić et al., 2010). Data for gross margin calculations were collected through the questionnaire from the representative farm in Pomoravlje region (village Končarevo) in 2012.

For calculating the basic elements of gross margin, following data were used: data on yield and price; by-product price; seed cost; quantity and value of fertilizers, pesticides, and fuel; and costs of contracted services. Indicators for the value of production, total variable costs and gross margin were calculated according to methodology provided by Agriculture Extension Service of Serbia website (www.psss.rs). Microsoft Excel was used for processing data and calculating the average gross margin for corn, soybean and wheat, elements of revenue and expenditures. The programme was adjusted to calculate the average value of each element of the calculation ${ }^{5}$.

\section{Risk assessment}

There are only two methods to evaluate the suitability of a field for growing corn in continuation. The first method is based on a detailed check of 40 plants, on a weekly basis. One check consists of careful examination of two plants, which means that one should take 20 evenly dispersed samples from a single filed. A samples order in a field should be in an inverted 'U' shape. Every plant should be up to $3 \mathrm{~m}$ apart from another (Edwards et al., 1994). To get rid of the edge effect, the first sample should be taken from a distance of at least 25 rows away from the edge of the corn field. Beside the average number of adults, this method of confirming the economic damage threshold also takes into consideration the plant structure, frequency of growing corn, physical characteristics of the soil and the sex ratio in the pest on the particular plot. Based on these elements, tables with critical numbers are formed. Another method rationalizes the sampling process in terms of labour and time. It is primarily based on distinct differences in the density of Western corn rootworm populations in fields, and in the beginning of the assessment, it quickly discards plots with high abundance but, if abundance is low, the process stops until the next inspection.

Determining the number of populations of western corn rootworm was conducted on corn plots in Končarevo village, where the FFS - Farmer Field School was organized. Work with the farmers was organized in line with the principle of non-formal adult education (NFE) and they were trained how to determine the population size of western corn rootworm using a variety of methods, primarily the Agro Ecological System Analysis (AESA).

5 www.itecherpsolution.rs/bm/doc/bmuputstvopsenicauproscena.pdf, www.itecherpsolution. rs/bm/doc/bmobrazacpsenicauproscena.xls 


\section{Method of Non-Formal Adult Education}

When working with farmers, we used methods of non-formal adult education (NFE) (Callo et al., 1999), and "Farmer Field School" (Gallagher, 1996; Pontius et al., 2002; Stanković, Sivčev 2004; Berg, 2004; Sivčev, Rahović, 2008), as well as the Agro Ecological System Analysis. As a developed and efficient method of counselling, non-formal education is a training method based on assumptions about the learning process of adults, who differ from children on their way of learning, because they have already had some experience, knowledge and skills, as well as their own beliefs, values, prejudices, preferences etc. Adults normally go through certain stages of the learning cycle. These stages are testing, analysing, processing and generalizing. This makes farmers a significant factor in the training process, so their active participation is very important and their training is conducted in phases (experiential learning, making analyses and generalization) that repeat cyclically (FAO, 2004). The "Farmer Field School" model links farmers, who are equal partners in finding locally adapted cropping practices and pest management. The costs of farmer field schools are small and correspond to the economic strength of these small-scale farmers. This model can be applied to all cases where knowledge and skills are required and human labour is necessary, regardless plot size, such as in organic production of strawberries and raspberries, or glasshouse vegetable production. It is also applicable in production of field crops grown on large areas and giving relatively low yields, like corn, which cannot be burden with new costs because this production would not be cost-effective.

\section{Agro Ecological System Analysis (AESA)}

The Agro Ecological System Analysis involves careful consideration of all available techniques (ways) of pest control (suppressing), and their later integration in the production, reducing pest development in order to control the use of pesticides at an economically justified level, which would lead to reducing risks to human health and the environment. The integrated pest management (IPM) emphasizes and points out the cultivation of a healthy crop with minimum disruption of the agro ecological system, encouraging and spreading mechanisms of natural pest control (FAO, 2004). The most important cropping measures in integrated pest management are: Crop rotation, Choice of varieties and hybrids, Tillage, Spatial isolation, Irrigation, Sowing, planting, Weed control, Harvest, picking and collecting products.

The main goal of sustainable agriculture is the advancement of agricultural production in order to create higher profits while protecting the environment, people and animals.

Therefore IPM is based on four practical principles (FAO, 2004):

1. Grow healthy crops: grow varieties resistant to major pests and diseases, yet completely adapted to the local environment; proper implementation of cropping practices (pruning, fertilization, and irrigation), necessary for healthy plants. A healthy, robust plant is a primary goal of the IPM method - it can resist diseases and compensate damages caused by insects, so that damage does not always have to lead to excessive yield losses. 
2. Preserve natural enemies: in all agricultural ecosystems there are predators, parasites and diseases that attack pests in egg, larva, pupa and adult stages. These natural enemies are often found in the field and they are "friends of farmers" because they can biologically control pests. IPM training mainly focuses on how to identify and manage these natural enemies so that they would not be destroyed with excessive use of pesticides.

3. Regular field observation: it is necessary to assess the dynamics of crop pests and natural enemies, diseases, weeds and weather conditions. An IPM trained farmer typically does this during regular activities of crop care. Observations should determine the condition of a crop and whether there are some pests or diseases that could cause yield losses. It is important to remember that not all damages lead to yield losses.

4. Farmers become experts: the emphasis is on improving the ability of farmers to make better decisions, increase their efficiency and manage their farms better. The future of production and food security depends on how farmers innovate and manage the system. The success of IPM depends on farmers and therefore it put emphasis on their skills and knowledge.

The content of the AESA training and programs for farmers include: field analysis, samples analysis, discussion and specific topics.

An example of the agenda and the content of activities of a "Farmer Field School" used in work with farmers from Končarevo, and the content of the Agro Ecological System Analysis, would look like this (Sivčev, Rahović, 2008):

- Observation of the experimental field: farmers in small groups monitor and record changes in their experiment throughout the season.

- Analysing the differences between different settings of the experiment.

- Discussing the effectiveness of different methods: making conclusions and giving recommendations for the further work.

Introducing sustainable methods of monitoring the occurrence and abundance of western corn rootworm

As has been mentioned, pheromone traps are the most accurate way to determine the maximum number of adult insects because they show the state of the population in a wider area, attracting insects from a distance greater than $100 \mathrm{~m}$. Setting standards for our climate conditions makes it possible to organize a broad-based education / training for agricultural extension agents on the principles of non-formal education (NFE), and also directly or indirectly, training for a large number of primarily "'medium and small-scale farmers" (FFS) on visual assessment and determination of the abundance of harmful species. This ensures a massive and broad territorial coverage of corn fields, for monitoring and predicting the occurrence of Western corn rootworm in repeated sowing. 


\section{Effects of using Farmer Field Schools}

Growing crops that increase the farm income is one of the ways to "add value (revenue) to the production" of an individual farm, as well as to strengthen the competitiveness of country's agriculture and foster rural development. When it comes to farmers as users of advisory services, they can be divided into two groups: 1) a small number of large-scale farmers, who can pay for advisory services, and 2) small-scale farmers, who will not be able to pay for these services in the foreseeable future.

The Agricultural Extension Service (PSSS) should be able to provide consulting services to specialized farms, which are commercial producers, as well as a large number of small farms, small households with a few acres of land. On these farms they are only members of the family who work, they have very little training on the organization and their production is generally mixed. In our country there is no effective method how to improve the production and quality of agricultural products of small-scale farmers. They are very numerous, having different products, production of which can hardly be characterized as commercial by the standards of the developed countries.

On the one hand, these farmers cannot pay for advisory services, and on the other hand, PSSS cannot assist them by visiting each household. Worldwide, it is of great importance for an extension service to work with farmer groups to achieve the efficiency. Experience in working with such farmers has shown that the results are positive when the significance and solution of a problem are determined from the standpoint of small-scale farmers, i.e. when the problem is solved in a sustainable manner. With this approach, the interests of small-scaled farmers are ensured who are then happy to engage in group work and achieve massive and quality production without any major problems.

This model can be applied to all cases when knowledge and skills are needed and human labour is necessary, regardless the size of the property. In a "Farmer Field School" (FFS), all the parties involved are equal partners in finding a locally adapted practice of crop and pest management. In a "Farmer Field School", farmers are not just passive recipients of some technical information, but they are given the opportunity to actively learn and therefore achieve better control over conditions they face in their fields every day. In this way, farmers can manage the ecological principles that should apply to their fields and become experts in integrated production and protection. Finally, collaboration and circulation of information among farmers gathered in FFS provide a far greater effect of environmental management of WCR than the application on individual fields.

\section{Results and Discussion}

This study proves that crop rotation is an efficient strategy for control of this pest in our conditions. In a crop rotation system, during the first year of growing corn, there was a small population of this pest when sampling, and only in a few cases $(1.17 \%)$ the pest was present in numbers close to the economic tolerance threshold. When the abundance was determined, it was usually on adjacent fields that were under repeated corn sowing. Although root damage was not the matter of investigation, some obvious symptoms of 
damage, such as plant lodging, were not registered in the first year. Since most of these fields were characterized to be below the economic threshold of six adults (beetles) per trap per day, Serbian corn producers could sow corn again with a relatively low risk for roots to be significantly damaged in the upcoming year. However, in the midst of Western corn rootworm occurrence most corn producers resorted to crop rotation. A similar situation happened in Central Europe. In experiments with crop rotation in Hungary, Kiss et al. (2005) observed the numbers of insects were lower in rotation when compared to the continuous corn sowing. Crop rotations of corn, soybean and sunflower were effective in minimizing the population of Western corn rootworm. It is possible that the diversity of vegetation played a role in the effectiveness of crop rotation. Moeser and Vidal (2004) showed that an expanded food selection present in South eastern Europe, had contributed to the successful invasion of pests in Europe, but it is also possible that it had happened due to reducing the selection pressure for pests to lay eggs out of corn. This suggests that crop rotation and the diversity of agricultural crops can significantly reduce the risk of high population abundance of Western corn rootworm.

In fields where corn is grown continuously (repeated sowing) population density of Western corn rootworm slowly increases with the number of years of repeated sowing. Thus, the mean number of pest populations in years 1-5 in repeated sowing increases from $1.17,4.61,6: 41$, and 10.30 to $13: 53$ adult per trap per day. In the case of continuous sowing, the presence of food is not considered to be a limiting factor for the increase in number of the population. In 2000, an unusually dry and warm summer resulted in a high mortality of eggs. Not fulfilling its potential fertility is probably the main reason why Western corn rootworm populations are not higher or they are even reduced. Similar conclusions can be drawn from the results of this study. The influence of unfavourable environmental conditions in 2000 was seen in corn fields in all areas, especially in Eastern Serbia, where it was very difficult to find damaged fields and fields with populations above the economic threshold in the next year (2001). Moreover, in 2003 the weather conditions were again extreme, with low precipitation and high temperatures, which also contributed to the reduction of pest populations. Another example of the impact of adverse weather conditions was registered in the spring of 2005, when the frequent and heavy precipitation was caused by excessive soil moisture and flooding. Due to these specific conditions, sowing was delayed, resulting in low population density in many corn fields.

The research by Wilson et al. (2005) showed that the majority (75.2\%) of farmers in five U.S. states in the Corn Belt use crop rotation to control Western corn rootworm. In our study, farmers used crop rotation as a traditional practice, not only for the management of Western corn rootworm, but also for weeds and diseases. However, based on corn fields analysed in our study, it does not seem that all the fields rotated on annual basis. The farmers in our study generally used corn rotating below the economic threshold.

Onstad et al. (2003) pointed out that in Eastern and Central Illinois in case of continuous corn sowing ( $2-9 \%$ on average) it takes 16 years until the pest become resistant to crop rotation. In Serbian agro ecological conditions, due to the occurrence of Western corn 
rootworm and severe damages registered in the early stage, the share of corn that once was more than $30 \%$ has been reduced to about $0 \%$. Under the given conditions, the ratio of corn and non- corn fields was about 50:50, which means that farmers rotated crops annually (Sivčev, Galo, 2001). Crop rotation is used by many farmers because it is very efficient, and the total density of WCR population has been therefore significantly reduced.

In our sample, $87.8 \%$ of the fields had no economically harmful population of WCR. As it can be expected, the share of fields with population density below the economic threshold decreases with increase in number of years of repeated corn sowing. The share of fields under corn production (1.2 million ha) in total arable land available (3.3 million ha - 36.4 $\%$, indicating that the complete corn production can be protected by using crop rotation. It is clear that the selection pressure for WCR populations resistant to rotation is not high. Based on these data, it appears unlikely that WCR populations will develop resistance to rotation. Our data encourage the idea of crop rotation sustainability, previously pointed out by Miller et al. (2007). Moreover, what this data indicate is a generally low level of genetic differentiation between the variants and wild-type WCR populations. Currently, WCR is not an invasive pest species in Serbia, but it is considered as a well-established economically important pest, which can efficiently manage crop rotation (Sivčev et al., 2009; Stanković, 2012). Therefore, a need for effective and long-term control of WCR should primarily rely on encouraging the diversity of crops.

\section{Gross Margins of Different Enterprises - Wheat Production}

The size of an estate and the acreage of the used agricultural land are certainly not information on which we can evaluate the performance of a farm. Even when we have data on what is produced, we must know when and how much is produced. Based on these data, we can compare the performance of individual production lines and make decisions on the future structure of production. One of the derived indicators that can be used as a criterion for determining this structure is the gross margin. Of course, the gross margin is not the most important and the only criterion, but it can be a starting point that does not require numerous and complicated data and methods.

A gross margin of enterprises in one year can be represented by using the data for the same production line obtained from different farms. Gross profit margin does not indicate profits and it does not include the size, and value of fixed costs. It represents the total value of production subtracted by the direct costs of investments (purchased inputs).

In 2012, on one farm, wheat was sown on 5 ha. The average yield of mercantile wheat on that farm was $4.00 \mathrm{t} / \mathrm{ha}$. With an average price of $25,000.00 \mathrm{RSD} / \mathrm{t}$ the value of the main commodity was $100.000,00 \mathrm{RSD} / \mathrm{ha}$, which with the subsidy of 9,220.00 RSD/ha gave the total production value of 109,220.00 RSD/ha. The cost of inputs per unit was 49,710.00 $\mathrm{RSD} /$ ha on average.

The most important items in the direct (variable) costs were mineral fertilizer (51.30\%), fuel $(23.53 \%)$, seed (23.23\%), and chemical products - pesticides (only 1.93\%). 
The realized gross margin was 59,510.00 RSD/ha, where:

Critical price was $12.43 \mathrm{RSD} / \mathrm{kg}$ and

Critical yield was $1,988.00 \mathrm{~kg} / \mathrm{ha}$.

After conducting the sensitivity analysis, and monitoring the variations in gross margins when the offering and selling price or both parameters range $+/-20 \%$, it was noted that the gross margin could become negative only when yield and / or market price reduced for $50 \%$.

Table 1. Gross margin for wheat production in Končarevo village

\begin{tabular}{|c|c|c|c|c|c|c|}
\hline \multirow{2}{*}{\multicolumn{2}{|c|}{ 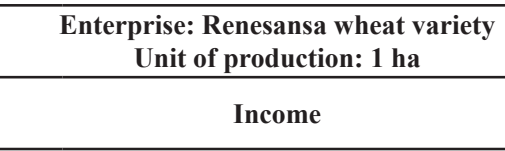 }} & \multicolumn{5}{|c|}{ Končarevo village } \\
\hline & & Quantity & MU & Price & MU & $\begin{array}{c}\text { Amount } \\
\text { (RSD) }\end{array}$ \\
\hline 1. & Wheat grain & 4,000 & $\mathrm{~kg} / \mathrm{ha}$ & 25 & $R S D / \mathrm{kg}$ & $100,000.00$ \\
\hline 2. & Field crops subsidy & 1 & $R S D / h a$ & 6,420 & $R S D / h a$ & $6,420.00$ \\
\hline 3. & Fuel subsidy & 40 & $R S D / h a$ & 70 & $R S D / h a$ & $2,800.00$ \\
\hline A. & Total income & & & & & $109,220.00$ \\
\hline \multicolumn{7}{|c|}{ Variable costs } \\
\hline 1. & Seed & 350 & $\mathrm{~kg} / \mathrm{ha}$ & 33 & RSD/s.u. & $11,550.00$ \\
\hline \multirow[t]{3}{*}{2.} & \multicolumn{6}{|l|}{ Fertilizer } \\
\hline & a) NPK & 350 & $\mathrm{~kg} / \mathrm{ha}$ & 50 & $R S D / k g$ & $17,500.00$ \\
\hline & c) KAN & 250 & $\mathrm{~kg} / \mathrm{ha}$ & 32 & $R S D / \mathrm{kg}$ & $8,000.00$ \\
\hline \multirow[t]{2}{*}{3.} & \multicolumn{6}{|l|}{ Pesticide } \\
\hline & a) Monosan herbi & 2 & $l(\mathrm{~kg}) / \mathrm{ha}$ & 480 & $R S D / \mathrm{kg}$ & 960.00 \\
\hline \multirow[t]{7}{*}{4.} & \multicolumn{6}{|l|}{ Diesel fuel } \\
\hline & Basic and additional tillage & 30 & l/ha & 130 & $R S D / l$ & $3,900.00$ \\
\hline & Fertilizing & 15 & l/ha & 130 & $R S D / l$ & $1,950.00$ \\
\hline & Sowing & 15 & l/ha & 130 & $R S D / l$ & $1,950.00$ \\
\hline & Measures of care and protection & 10 & l/ha & 130 & $R S D / l$ & $1,300.00$ \\
\hline & Transportation & 10 & l/ha & 130 & $R S D / l$ & $1,300.00$ \\
\hline & Harvest & 10 & l/ha & 130 & $R S D / l$ & $1,300.00$ \\
\hline 5. & \multicolumn{6}{|l|}{ Contracted services } \\
\hline & Sowing & & $h a$ & & RSD/ha & - \\
\hline & Harvest & & $h a$ & & $R S D / h a$ & - \\
\hline & Labour & & $h a$ & & $R S D / h a$ & - \\
\hline B. & Total variable costs & & & & & $49,710.00$ \\
\hline C. & Gross margin $(A-B)$ & & & & & $59,510.00$ \\
\hline
\end{tabular}

Source: Authors' calculation based on data from PSSS Jagodina questionnaire (2012). 


\section{Soybean Production}

In 2012, soybeans were planted on 2.0 ha of a selected farm. The average yield of soybeans was $2.0 \mathrm{t} / \mathrm{ha}$. With an average price of $65,000.00 \mathrm{RSD} / \mathrm{t}$, the value of the main commodity was $130,000.00 \mathrm{RSD} / \mathrm{ha}$, which with the subsidy of $12,000.00 \mathrm{RSD} / \mathrm{ha}$, gave the total production value of $142,000.00 \mathrm{RSD} / \mathrm{ha}$.

Total variable costs per unit, were $69,590.00 \mathrm{RSD} /$ ha on average.

The most important items in the direct (variable) costs were fertilizer and pesticide (30.17\%), fuel (15.89\%) and seed (15.02\%).

The realized gross margin was $72,410.00 \mathrm{RSD} / \mathrm{ha}$, where:

Critical price was $34.80 \mathrm{RSD} / \mathrm{kg}$ and critical yield was $1,070.62 \mathrm{~kg} / \mathrm{ha}$.

Table 2. Gross margin for soybean production in Končarevo village

\begin{tabular}{|c|c|c|c|c|c|c|}
\hline \multicolumn{3}{|c|}{$\begin{array}{l}\text { Enterprise: BALKAN soybean variety } \\
\text { (Unit of production: } 1 \text { ha) }\end{array}$} & \multicolumn{4}{|c|}{ Končarevo village } \\
\hline & Income & Quantity & MU & Price & MU & Amount (RSD) \\
\hline 1. & Soy bean & 2,000 & $\mathrm{~kg} / \mathrm{ha}$ & 65 & $R S D / k g$ & $130,000.00$ \\
\hline 2. & Field crops subsidy & - & RSD/ha & - & $R S D / k g$ & - \\
\hline 3. & Fuel subsidy & 1 & $R S D / h a$ & 12,000 & $R S D / h a$ & $12,000.00$ \\
\hline A. & \multicolumn{5}{|l|}{ Total income } & $142,000.00$ \\
\hline \multicolumn{7}{|c|}{ Variable costs } \\
\hline 1. & Seed & 110 & $\mathrm{~kg} / \mathrm{ha}$ & 95 & $\operatorname{din} / s . u$. & $10,450.00$ \\
\hline 2. & \multicolumn{6}{|l|}{ Fertilizer } \\
\hline & a) NPK & 300 & $\mathrm{~kg} / \mathrm{ha}$ & 50 & $R S D / k g$ & $15,000.00$ \\
\hline & c) $\mathrm{KAN}$ & 200 & $\mathrm{~kg} / \mathrm{ha}$ & 30 & $R S D / k g$ & $6,000.00$ \\
\hline 3. & \multicolumn{6}{|l|}{ Pesticide } \\
\hline & a) Afalon & 2 & $l(\mathrm{~kg}) / \mathrm{ha}$ & 2130 & $R S D / l(\mathrm{~kg})$ & $4,260.00$ \\
\hline & b) Dual & 1,5 & $l(\mathrm{~kg}) / \mathrm{ha}$ & 2320 & $R S D / l(k g)$ & $3,480.00$ \\
\hline & c) Pulsar & 1 & $l(\mathrm{~kg}) / \mathrm{ha}$ & 5150 & $R S D / l(k g)$ & $5,150.00$ \\
\hline & d) Ritam & 1 & $l(\mathrm{~kg}) / \mathrm{ha}$ & 3200 & $R S D / l(k g)$ & $3,200.00$ \\
\hline 4. & \multicolumn{6}{|l|}{ Diesel fuel } \\
\hline & Basic and additional tillage & 35 & l/ha & 130 & $R S D / l$ & $4,550.00$ \\
\hline & Fertilizing & 10 & l/ha & 130 & $R S D / l$ & $1,300.00$ \\
\hline & Sowing & 10 & $l / h a$ & 130 & $R S D / l$ & $1,300.00$ \\
\hline & Measures of care and protection & 15 & $l / h a$ & 130 & $R S D / l$ & $1,950.00$ \\
\hline & Transportation & 15 & $l / h a$ & 130 & $R S D / l$ & $1,950.00$ \\
\hline & Harvest & & $l / h a$ & 130 & $R S D / l$ & - \\
\hline 5. & \multicolumn{6}{|l|}{ Contracted services } \\
\hline & Sowing & & $h a$ & & $R S D / h a$ & - \\
\hline & Harvest & 1 & $h a$ & 11,000 & $R S D / h a$ & $11,000.00$ \\
\hline & Labour & & $h a$ & & $R S D / h a$ & - \\
\hline B. & \multicolumn{5}{|l|}{ Total variable costs } & $69,590.00$ \\
\hline C. & \multicolumn{5}{|l|}{ Gross margin $(A-B)$} & $72,410.00$ \\
\hline
\end{tabular}

Source: Authors' calculation based on data from PSSS Jagodina questionnaire (2012). 
After completion of the sensitivity analysis, and monitoring variations in gross margins when offering and selling price, or both parameters in the range $+/-20 \%$, it was noted that gross margin could become negative only in the case of a reduction of yield and / or the market price, for about $50 \%$.

\section{Corn Production}

In 2012, corn was planted on 10 ha of a selected farm. The average grain yield was $5 \mathrm{t} /$ ha. With an average price of $26,000.00 \mathrm{RSD} / \mathrm{t}$, the value of the main product is $130,000.00$ $\mathrm{RSD} /$ ha, achieved with $6,420.00 \mathrm{RSD} /$ ha subsidy, which gives a total production value of 136,420.00 RSD/ha.

Total variable costs per unit are 44,372.50 RSD/ha on average.

The most important items in the direct (variable) costs consist of: mineral fertilizer $(52.06 \%)$, followed by fuel $(26.95 \%)$, seed $(11.72 \%)$ and, finally, protective equipmentpesticides $(9.27 \%)$.

Table 3. Gross margin for corn production in Končarevo village

\begin{tabular}{|c|c|c|c|c|c|c|}
\hline \multicolumn{3}{|c|}{$\begin{array}{l}\text { Enterprise: ZP } 704 \text { corn variety } \\
\text { (Unit of production: } 1 \text { ha) }\end{array}$} & \multicolumn{4}{|c|}{ Končarevo village } \\
\hline & Income & Quantity & MU & Price & MU & Amount (RSD) \\
\hline 1. & Corn grain & 5,000 & $\mathrm{~kg} / \mathrm{ha}$ & 26 & $R S D / k g$ & $130,000.00$ \\
\hline 2. & Field crops subsidy & 1 & $R S D / h a$ & 6,420 & $R S D / h a$ & $6,420.00$ \\
\hline 3. & Fuel subsidy & & $R S D / h a$ & & $R S D / h a$ & - \\
\hline A. & Total income & & & & & $136,420.00$ \\
\hline \multicolumn{7}{|c|}{ Variable costs } \\
\hline 1. & Seed & 2 & s.u./ha & 2,600 & RSD/s.u. & $5,200.00$ \\
\hline 2. & \multicolumn{6}{|l|}{ Fertilizer } \\
\hline & a) NPK & 270 & $\mathrm{~kg} / \mathrm{ha}$ & 50 & $R S D / k g$ & $13,500.00$ \\
\hline & b) UREA & 200 & $\mathrm{~kg} / \mathrm{ha}$ & 48 & $R S D / \mathrm{kg}$ & $9,600.00$ \\
\hline 3. & \multicolumn{6}{|l|}{ Pesticide } \\
\hline & a) Acetogal & 2 & $l(\mathrm{~kg}) / \mathrm{ha}$ & 650 & $R S D / \mathrm{kg}$ & $1,300.00$ \\
\hline & b) Tangenta & 1.25 & $l(\mathrm{~kg}) / \mathrm{ha}$ & 1450 & $R S D / \mathrm{kg}$ & $1,812.50$ \\
\hline & c) Cambio & 1 & $l(\mathrm{~kg}) / \mathrm{ha}$ & 1000 & $\mathrm{RSD} / \mathrm{kg}$ & $1,000.00$ \\
\hline 4. & \multicolumn{6}{|l|}{\begin{tabular}{|l} 
Diesel fuel \\
\end{tabular}} \\
\hline & Basic and additional tillage & 35 & $l / h a$ & 130 & $R S D / l$ & $4,550.00$ \\
\hline & Fertilizing & 10 & $l / h a$ & 130 & $R S D / l$ & $1,300.00$ \\
\hline & Sowing & 10 & $l / h a$ & 130 & $R S D / l$ & $1,300.00$ \\
\hline & Measures of care and protection & 12 & l/ha & 130 & $R S D / l$ & $1,560.00$ \\
\hline & Transportation & 10 & $l / h a$ & 130 & $R S D / l$ & $1,300.00$ \\
\hline & Harvest & 15 & $l / h a$ & 130 & $R S D / l$ & $1,950.00$ \\
\hline 5. & \multicolumn{6}{|l|}{ Contracted services } \\
\hline & Sowing & & $h a$ & & $R S D / h a$ & - \\
\hline & Harvest & & $h a$ & & $R S D / h a$ & - \\
\hline & Labour & & $h a$ & & $R S D / h a$ & - \\
\hline B. & \multicolumn{5}{|l|}{ Total variable costs } & $44,372.50$ \\
\hline C. & \multicolumn{5}{|l|}{ Gross margin $(\mathrm{A}-\mathrm{B})$} & $92,047.50$ \\
\hline
\end{tabular}

Source: Authors' calculation based on data from PSSS Jagodina questionnaire (2012). 
The achieved gross margin is $92,047.50 \mathrm{RSD} / \mathrm{ha}$, where:

Critical price was $8.87 \mathrm{RSD} / \mathrm{kg}$ and critical yield was $1,706 \mathrm{~kg} / \mathrm{ha}$.

After conducting the sensitivity analysis, and monitoring the variations in gross margins when the offering and selling price or both parameters range $+/-20 \%$, it was noted that the gross margin could become negative only when yield and/or market price reduced for $65.8 \%$.

Since we assumed that all enterprises are burden by the same fixed costs in one production cycle, the gross margin for 2012 presented the data for the three enterprises taken from a reputable, market-oriented farm. The highest average gross margin on the farm in 2012 , was achieved with corn (92,047.50 RSD/ha), and soybeans (72,410.00 RSD/ha) and the lowest with wheat production (RSD 59,510.00/ha). In these three enterprises, there were no big differences in the value of the gross margins, ranging from 1:1.22 between wheat and soybeans; $1: 1.55$ between wheat and corn and 1:1.27 between soybeans and corn.

The largest direct investments for inputs were required by soybean production $-69,590.00$ $\mathrm{RSD} /$ ha and the lowest by corn production 44,372.00 RSD/ha.

The value of production was highest in soybean (142,000.00 RSD), slightly higher than in corn $(136,420.00$ RSD), and significantly higher than in wheat production $(109,220.00)$. Comparing the yields and costs per ton of product does not make difference because different types of production were observed. The data we used in the calculation of gross margins, we can use for giving recommendations, planning and determining the structure of crop production, based on investments that the obtained values require.

This clearly suggests that corn has the highest gross margin with the least investments. Due to good and timely used cultivation technology, the chosen farm managed to achieve the yields even in extremely hot/dry 2012, which certain farms cannot achieve in more favourable conditions. The crucial role in this truly homely business had:

1. The needs of the farm, in terms of having sufficient and good quality animal feed,

2. Crop rotation, to what great attention was paid, considering the high yields achieved on the farm every year, partially due to the three-field system instead of the two-field system with a monoculture,

3. Monitoring of market trends and investments in the production of industrial crops.

Also, comparing to results described by Tomić et al., (2013), gross margin for corn, calculated based on questionnaire carried out 2012 on a total of 69 chosen leader farms from the territory of 11 stations of the Agricultural Extension Service of Serbia, was higher at our leader farm (92,047.50 RSD compared to 64,257.00 RSD). Yield was higher at observed leader farm (5000 kg/ha) compared to Central Serbia average $(4,572 \mathrm{~kg} / \mathrm{ha})$. The difference was primarily due to calculated subsidies, but the most important difference was lower costs, especially for fertilizers $23,100.00$ RSD compared to 30,036.00 RSD as an average in Central Serbia. 


\section{Conclusion}

The results of this research are supposed to demonstrate the efficiency and sustainability of environmental management in solving problems of corn protection. These conclusions can be reached only if they learn and discover through their production practices. It is therefore to be expected that the applied methodology with Farmers field schools might be a results.

Crop rotation as a tool for management and control of corn rootworm and in terms of various biodiversity is the only efficient and cost-effective measure, but only in circumstances where it is absolutely necessary.

The main objective of the activity is the training of advisors to develop and implement programs in solving problems that small scale farmers have in production. Training is provided through a theoretical overview of the methodology and demonstration program of activities on existing projects, and later using specific tools. This will begin the process of creating an environment for the promotion of agricultural production and the quality of agricultural products of small scale farmers using the methodology of working with groups and the intention to first highlight the interest of small scale farmers to get their problems solved.

Significant increase in the dissemination of knowledge in the field (in the villages). The basis for the implementation of these activities, group work with farmers (Farmer Field Schools - FFS) and the dissemination of knowledge on the principle of "farmer to farmer". If we calculate the average of 10 farmers trained by the group on an annual basis, the total number of trained farmers who are able to improve efficiency in agricultural production, as well as providing information to its neighbours, would be significant.

The effect will result in great savings in unnecessary application of chemicals and environmental pollution, but also unnecessary application of crop rotation, which is important in specialized corn producers.

Gross margin of three production lines at the participant's farms in training programs, have shown that corn has the highest gross margin (with the least investment).

Due to good and timely used cultivation technology, the chosen farm managed to achieve the yields even in extremely hot/dry 2012, which certain farms cannot achieve in more favourable conditions.

Calculations of production of wheat, corn and soybean on farms involved in education program in 2012, have shown that corn has the highest gross margin $(92,047.50 \mathrm{RSD} / \mathrm{ha})$, followed by soybean $(72,410.00 \mathrm{RSD} / \mathrm{ha})$ and wheat $(59,510.00 \mathrm{RSD} / \mathrm{ha})$. Lower costs, especially for fertilizers and other unnecessary inputs lead to higher gross margins.

Traditional corn production in the village Koncarevo, at the farm of participants in the education program justifies the continuation of corn growing at the same field, with a mandatory risk assessment of repeated sowing. Gross margin calculated on leader and other farms within the regular activities of Agriculture Advisory Services is a powerful toll for assessing the efficiency of advisory work. 


\section{References}

1. Anđelić, B., Janković, S., Tomić, V. (2010): Uticaj strukture ratarske proizvodnje na bruto marzu porodicnih gazdinstava, Poljoprivredne aktuelnosti, Institut za primenu nauke u poljoprivredi, Beograd, br. 1-2, pp. 92-104.

2. Berg, H. van den (2004): IPM Farmer Field Schools: A synthesis of 25 impact evaluations, Wageningen University, Prepared for the FAO Global IPM Facility.

3. Callo, D. P., Cuaterno, W. R., Tauli, H. A. (1999): Handbook of Non - Formal Education and Team Building Exercises for Integrated Pest Management, The Philippine National IPM Programme (Kasakali late) ASEAN IPM Knowledge Network, SEAMEO research, the Philippines.

4. Edwards, C. R., Larry, W. B., Turpin, F. T. (1994): Field crop insects managing corn rootworms 1994, Purdue University, Cooperative Extension Service, E-49, pp. 1-6, West Lafayette.

5. FAO (2004): A Facilitator's Field Guide to Integrated Pest Management for Western Corn Rootworm in Central and Eastern Europe, A Training Resource Manual on Planning, Organizing, and Implementing Farmer Field Schools for Integrated Pest Management in Corn in Central and Eastern Europe.

6. Gallagher, K. (1996): Community-based rice IPM Programme Development: A Facilitator's guide, FAO Inter - Country Rice Integrated Pest Management Programme for Asia, Manila, Philippines.

7. Gray, M. E., Levine E., Oloumi-Sadeghi, H. (1998): Adaptation to crop rotation: Western and northern rootworms respond uniquely to a cultural practice, Recent Res. Devel. in Entomology, vol. 2, pp. 19-31.

8. Janković, S., Goss, S., Pusic, M., Jovanovic, R., Todorovic, G., Tolimir, N., Ivkov, I., Andjelic, B., Dalton, G. (2007): Poslovanje poljoprivrednih gazdinstava u Srbiji 2006, Priručnik, Institut za primenu nauke u poljoprivredi, Beograd, pp. 26-27.

9. Kiss, J., Edwards, R., Berger, H. K., Cate, P., Cean, M., Cheek, S., Derron, J., Festic, H., Furlan, L., Igrc-Barcic, J., Ivanova, I., Lammers, W., Omelyuta, V., Prinzinger, G., Reynaud, F., Sivcev, I., Sivicek, P., Urek, G., Vahala, O. (2005): Monitoring of Western Corn Rootworm (Diabrotica virgifera virgifera LeConte) in Europe 19922003, In: Western Maize Rootworm: Ecology and Management (Ed. Vidal, S., Kuhlman, U. and Edwards C.R.), CABI International, pp. 29-39.

10. Miller, N. J., Ciosi, M., Sappington, T. W., Ratcliffe, S. T., Spencer, J. L., Guillemaud, T. (2007): Genome scan of Diabrotica virgifera virgifera for genetic variation associated with crop rotation tolerance, J. Appl. Entomol., no. 131, pp. 378-385.

11. Moeser, J., Vidal, S. (2004): Nutritional resources used by the invasive maize pest Diabrotica virgifera virgifera in its new South-east-European distribution range, Entomol. Exp. Appl., no. 114, pp. 55-63.

12. Munćan, P., Živković, D. (2006): Menadzment ratarske proizvodnje, Poljoprivredni fakultet, Beograd. 
13.Onstad, D. W., Crowder, D. W., Mitchell, P. D., Guse, C. A., Spencer, J. L., Levine, E. (2003): Economics versus Alleles: Balancing Integrated Pest Management and Insect Resistance Management for Rotation-Resistant Western Maize Rootworm (Coleoptera: Chrysomelidae), J. Econ. Entomol., no. 96, pp. 1872-1885.

14.Pontius, J., Dilts, R., Bartlett, A. (eds.) (2002): From farmer field school to community IPM. Ten years of IPM training in Asia, FAO Community IPM Programme, FAO Regional Office for Asia and the Pacific.

15. Agricultural Extension Service in Jagodina (PSSS Jagodina), (2012): Questionnaires carried out in 2012 on leader farms from the territory of Agricultural Extension Service in Jagodina (Pomoravlje region, Serbia), PSSS Jagodina, internal documentation.

16.Purdue University (1995): Corn and soybean field guide. Integrated pest management, Purdue University, Field crops IPM, available at: http://extension. entm.purdue.edu/fieldcropsipm/insects/corn-rootworms.php

17.Sivčev, I., Galo, A. (2001): Education as a factor in suppression of WCR in Serbia, XXI IWGO Conference, VIII Diabrotica Subgroup Meeting, Proceedings book, Padova, pp. 151-157.

18. Sivčev, I., Rahović, D. (2008): A Methodology for Working with Farmers on the Model of Adult and Non-formal Education "schools for farmers in the field", Handbook Project: Education Advisors for Improving Crop Production and Qualtures of Agricultural Products by Methods of Integrated Production and Non-formal Adult Education, the Institute for Science Application in Agriculture, Belgrade, pp. 1-10.

19.Sivčev, I., Stankovic, S., Kostic, M., Lakic, N., Popovic, Z. (2009): Population density of Diabrotica virgifera virgifera LeConte beetles in Serbian first year and continuous maize fields, J. Appl. Entomol., no. 133, pp. 430-437.

20. Statistical Office of the Republic of Serbia (SORS), (2014): Agriculture Census 2012, SORS, Belgrade, available at: http://popispoljoprivrede.stat.rs/

21.Stanković, S. (2012): Possible use of environmental management in control of invasive corn pest Diabrotica virgifera virgifera LeConte, Ph.D. thesis, Faculty of environmental protection, Educons University, Sremska Kamenica.

22.Stankovic, S., Sivčev, I. (2004): IPM for western corn rootworm participatory training through farmer field school in Serbia, IWGO, 10 ${ }^{\text {th }}$ Diabrotica subgroup meeting, Engelberg Switzerland, 14-16 January, Abstracts, p. 69.

23. Tomić, V., Janković, S., Kuzevski, J., Ljiljanić, N., Radišić, R. (2013): Maize gross margins in different environmental conditions in 2011 and 2012, Proceedings: Agriculture and rural development challenges of transition and integration processes, $50^{\text {th }}$ Anniversary Department of Agricultural Economics, Belgrade - Zemun.

24. Wilson, T. A., Rice, M. E., Tollefson, J. J., Pilcher, C. D. (2005): Transgenic corn for Control of the European Corn Borer and Corn Rootworms: a Survey of Midwestern Farmer's Practices and perceptions, J. Econ. Entomol., no. 98, pp. 237-247. 
Website:

25.www.itecherpsolution.rs/bm/doc/bmuputstvopsenicauproscena.pdf

26.www.itecherpsolution.rs/bm/doc/bmobrazacpsenicauproscena.xls

27.www.psss.rs

\title{
BRUTO MARŽA KAO POKAZATELJ ZNAČAJA EDUKACIJE POLJOPRIVREDNIKA O PROCENI RIZIKA OD KUKURUZOVE ZLATICE U PONOVLJENOJ SETVI
}

\author{
Jasmina Filipović ${ }^{6}$, Slađan Stanković ${ }^{7}$, Slobodan Ceranic ${ }^{8}$
}

\begin{abstract}
Sažetak
Kukuruzova zlatica (Diabrotica virgifera virgifera) je krajem 80-tih godina uneta na teritoriju Srbije i kao novo introdukovana štetna insekatska vrsta se brzo proširila po celoj teritoriji Srbije prouzrokujući štete. Tokom nekoliko godina praćenja pojave šteta primećeno je da plodored u našim uslovima pokazuje odlične rezultate. S druge strane, domaće životinje troše tokom uzgoja velike količine semena kukuruza, što sa obzirom na ograničen zemljišni fond obično znači učestalo gajenje kukuruza u ponovljenoj setvi ili u dugogodišnjoj monokulturi, a što povlači za sobom pojavu šteta od kukuruzove zlatice. Kroz škole u polju za poljoprivrednika (FFS), poljoprivrednici su edukovani o proceni rizika od kukuruzove zlatice pri ponovljenoj setvi kukuruza. Cilj je bio da se produži proizvodnju kukuruza u monokulturi, pod pretpostavkom veće profitabilnost proizvodnje kukuruza (bruto marža). Bruto marže tri linije proizvodnje na gazdinstvu ucesnika programa edukacije pokazale su da kukuruz ima najveću bruto maržu uz najmanja ulaganja (92,047.50 din/ ha), zatim soja (72,410.00 din/ha), a najmanju p̌̌enica (59,510.00 din/ha). Moglo bi se zaključiti da je najbolji interes farmera da gaje kukuru u monokulturi, kada je to moguće, uz obaveznu procenu rizika od ponovljene setve.
\end{abstract}

Ključne reči: kukuruz, kukuruzova zlatica, proizvodnja, bruto marža, ulaganje, cena, edukacija.

6 Jasmina Filipović, M.Sc., Poljoprivredna savetodavna i stručna služba Jagodina, Kapetana Koce 21, 35000 Jagodina, Srbija, Telefon: +381 35221 931, E-mail: mina66@open.telekom.rs

7 Dr Sladjan Stanković, Institut za primenu nauke u poljorivredi, Bulevar Despota Stefana 68b, 11000 Beograd, Srbija, Telefon: +381 6370038 62, E-mail: ssladjan@,beotel.net

8 Prof. dr Slobodan Ceranić, Poljoprivredni fakultet, Univerzitet u Beogradu, Nemanjina 6, 11080 Zemun, Srbija, Telefon: +381 1126153 15, E-mail: ceranic@agrif.bg.ac.rs

EP 2015 (62) 1 (137-153) 